\title{
The Reciprocal Relationship Between Earnings Management, Disclosure Quality and Board Independence: UK Evidence
}

\author{
Nooraisah Katmon ${ }^{1,2} \&$ Omar Al-Farooque ${ }^{3}$ \\ ${ }^{1}$ Faculty of Management and Economics, Sultan Idris Education University, Tanjung Malim, Malaysia \\ ${ }^{2}$ Accounting Research Institute, MARA University of Technology Malaysia, Malaysia \\ ${ }^{3}$ UNE Business School, University of New England \\ Correspondence: Nooraisah Katmon, Faculty of Management and Economics, Sultan Idris Education University, \\ Tanjung Malim, Malaysia. E-mail: nooraisah@fpe.upsi.edu.my
}

Received: October 10, 2019

Accepted: November 5, 2019

Online Published: December 23, 2019

doi:10.5430/rwe.v10n5p63

URL: https://doi.org/10.5430/rwe.v10n5p63

\begin{abstract}
We empirically examine the reciprocal relationships between disclosure quality, board independence and earnings management. Disclosure quality is measured using the IR Magazine Award, the number of forward looking information in the annual report as well as the analyst forecast accuracy. We estimate earnings management using modified Jones Model, while board independence is measured using the percentage of independent directors in the board. We remedied the simultaneity bias in our study using a simultaneous system of equation, which was estimated using two-stage least square regression (2SLS). Match-paired samples comprised of the winners and non-winners of the IR Magazine Award during the years from 2005-2008 were employed in our study. Our finding reported that there is a negative reciprocal relationship between disclosure quality and earnings management. We notice that these findings are robust across all disclosure quality measurement that we utilised in our 2 Stage Least Square (2SLS) regression. Only one way (negative) causality between board independence and earnings management is demonstrated (in the board independence equation). In regards to disclosure quality and board independence, we found mixed findings. In this instance, our result demonstrated that there is no reciprocal relationship between disclosure quality and board independence (measured using IRAWARD). Nonetheless, we reported a positive reciprocal relationship between board independence and disclosure quality when forward looking information is utilized as to represent disclosure quality and a negative relationship between these variables when analyst forecast accuracy is employed. Our finding suggests that future research should take into account the potential simultaneity bias when examining the relationship between disclosure quality, earnings management and board independence.
\end{abstract}

Keywords: co-determination, disclosure quality, earnings management, board independence

JEL Classification: M40, M41

\section{Introduction}

Our study empirically examines the reciprocal relationship between earnings management, disclosure quality, and board independence from the UK environment using two-stage least squares (2SLS) estimation. We intend to seek and provide better evidence in understanding the direction of causality for each of the endogenous variables (i.e., disclosure quality, earnings management and board independence), given that causality can run in either a one-way or two-ways direction. This is particularly important given that research (especially in the area of disclosure quality, earnings management and corporate governance) subject to the potential bias of reverse causality (Beyer et al., 2010; Brickley and Zimmerman, 2010; Brown et al., 2011; Hussain et al., 2019). Due to the lack of adequate evidence on the possible co-determination between endogenous variables, the potential two-way causality or simultaneity between one variable and another is unknown, and researchers are not able to grasp the size of detrimental bias introduced by endogeneity in their research.

\section{Theoretical Assumptions}

Managers may be motivated to disclose information by two contradictory factors. Disclosure quality is useful in reducing information asymmetry and agency cost (Glosten and Milgrom, 1985; Welker, 1995; Peterson and Plenborg, 2006; Jalloh and Guevera, 2017). Alternatively, disclosure may be motivated by other reasons that might increase 
agency cost. Specifically, the purpose of disclosure here is to increase managers' personal benefits, including bonuses and option grant. Brockman et al. (2011) reported that CEO's disclosure decision to release the negative or positive information to the market is related to his personal agenda, whether he plans to hold, buy or sell the shares, while Lang and Lundholm (2000) found that managers tend to improve firm's disclosure in order to increase the stock price.

Furthermore, certain types of forecasting disclosure such as management earnings forecast and analyst forecasts could possibly induce earnings management behaviour among the managers (Iatridis and Kadorinis, 2009), since the capital market reward the firms that are able to meet or beat a forecast, which signal that firms are performing well. High firm's disclosure will be rewarded by the capital market through an increase of share liquidity (Lang and Maffett, 2011), increase external equity (Myers and Majluf, 1984) as well as reducing the cost of capital (Botosan, 1997).

The notion that disclosure reduces information asymmetry, however, does not always tally with the empirical findings. Chang et al. (2008) find that investor relation disclosure is ineffective in reducing information asymmetry, after controlling for endogeneity. There is also evidence that forecasting activities do not necessarily motivate firms to manage earnings. Call et al. (2010) reports that firms that issue management earnings forecasts are associated with lower discretionary accruals, again suggesting that forecasting disclosure does not always motivate managers to manipulate earnings.

Demands for disclosure largely stem from information asymmetry and the separation of ownership and control (Beyer et al., 2010; Shleifer and Vishny, 1997). Good governance, of which embedded disclosure is part, is one form of monitoring tool that aims at reducing information asymmetry and conflicts of interest, resulting in lower agency cost (Holm and Schøler, 2010; Armstrong et al., 2010; Albasu and Nyameh, 2017). The identical function of disclosure and internal governance, although each component may contribute to a different extent to deterring agency cost, is largely presumed to carry a substitutive and/or complementary relationship, given that both of them are associated with cost and benefit trade-off (Donnelly and Mulcahy, 2008; Vafeas, 2005). Therefore, corporate governance mechanisms might be interrelated and endogenously determined. Given that internal and external governance tools are costly and subject to complementary or substitutive links, managers have incentives to choose the optimal mix of governance variables that fits with their needs and capacity (Holm and Schølar, 2010; Vafeas, 2005, Brick et al., 2008).

A part of the agency cost that is expected to be reduced as an outcome of proper disclosure and a sound governance system is earnings management behaviour, which Davidson et al. (2004) describe as the residual loss that occurs due to misalignment of interest between agent and principal. Aerts and Cheng (2011) opined that earnings management reduce the credibility of information, imposed agency cost and potentially diminish the accountability of the firms. As an antidote to earnings management, prior literature has demonstrated that disclosure transparency, corporate governance and low information asymmetry are associated with lower earnings management (for example Kent et al., 2010; Riahi and Arab, 2011; Jo and Kim, 2007; Trueman and Titman, 1988).

According to conventional wisdom, one would expect both disclosure and corporate governance to be negatively related to earnings management. However, the relationship is not straightforward and causality is hard to elucidate. Endogeneity and reverse causality make the relationship between disclosure, governance and earnings management complicated and hard to fully understand. Because of this, failure to consider this complexity causes one-way causality to be overrated and findings to be conflicting and inconclusive. Brickley and Zimmerman (2010) clearly mentioned that the relationship between corporate governance characteristics and financial reporting might have caused by the exogenous factors that co-determined each other. Beyer et al. (2010) also point out on the same issues by arguing that the studies on disclosure, governance, financial reporting, etc. are plagued with endogeneity problems which has caused difficulty in understanding the underlying caused and effects between them (Kheyfets and Chernova, 2019).

Having independent directors has been widely cited as one of the governance variables that suffer most from endogeneity as compared to other mechanisms in internal corporate governance class. Brick et al. (2008), Lim et al. (2007), Boone et al. (2007), Linck, Netter, and Yang (2008), Lehn et al. (2009), Coles, Daniel, and Lalitha (2008); Cornett et al. (2009), Bhagat and Black (2002), Adams and Ferreira, (2007) as well as Harris and Raviv, (2008) are examples of studies that have endogenised board independence variables, although some studies ignored the endogenous nature of board independence (e.g.Li et al., 2008; Patelli and Prencipe, 2007; Eng and Mak, 2003; Haniffa and Cooke, 2002). Besides the issue of possible simultaneity, board independence might be endogenous given that the "comply and explain" approach currently practised in the UK provides more freedom for managers to 
use their own discretion and judgement. This is especially the case when they are dealing with rules concerning independent directors.

With regard to disclosure quality, the endogenous nature of this variable stems from the flexibility applied in disclosure choices. In other words, managerial disclosure decisions might be influenced by considerations other than a wish to reduce information asymmetry. As discussed before, voluntary disclosure is subject to managers' discretion; so managers have an incentive to reveal information that can benefit them and hide other information that may not. Moreover, firms' voluntary disclosure decisions can also be shaped by other factors including managers' personal backgrounds such as education or military experience, (Bamber et al., 2010; Ashraf, Shafiq and Batool, 2017), nature of competitors (e.g. Botosan and Stanford, 2005; Verrecchia and Weber, 2006), as well as the regulatory environment in which the firm operates. Furthermore, disclosure has been discussed as endogenously related to the cost of capital (e.g. Clinch and Verrecchia, 2011), earnings management (e.g. Leuz et al., 2003; Zhou and Lobo, 2001) and corporate governance (e.g. Brown et al., 2011; Armstrong et al., 2010). (Note 1)

\section{Literature Review and Hypothesis Development}

\subsection{Disclosure Quality, Earnings Management and Board Independence}

Armstrong et al. (2010) put forward that more research on co-determination between disclosure, corporate governance and financial reporting is necessary to build understanding of causality between these endogenous variables. A US study by Cornett et al. (2009) uses 2SLS estimation to examine co-determination between firm performance, earnings management, CEO pay performance, board independence and capital ratio. They report a simultaneous relationship between earnings management and board independence, which suggests that firms with higher earnings management tend to have a lower number of independent directors on the board, while firms with a greater proportion of independent directors tend to exhibit higher earnings management. In regards to earnings management and firm performance, a reciprocal link is reported, where performance (earnings management) is negatively (positively) related to earnings management (performance) at $p<0.01$ and $p<0.01$ respectively. However, their study took place in the US where mandatory requirements are imposed on corporate governance standards; so these findings are not valid in countries like the UK which follow a "comply and explain" approach.

Toledo (2010) Spanish study examines the reciprocal relationship between governance characteristics and firm performance (where Tobin's Q is used as a proxy). He finds no reciprocal relationship between corporate governance and firm value, but a significant positive link between them at $\mathrm{p}<0.1$ (in the firm value equation). The study also reports a reverse causality association between board independence and firm value, where firm value is positively related to board independence at $\mathrm{p}<0.1$ (in the independent directors equation), but no simultaneous relationship is found.

Because only limited research has been conducted into the reciprocal relationship between disclosure quality, earnings management and board independence, especially in the UK environment, our study intends to fill this research void.

\subsection{Disclosure Quality and Earnings Management}

We notice that the association between disclosure quality and earnings management is inherently multifarious. While Leuz et al. (2003) and Zhou and Lobo (2001) highlight the endogenous nature of disclosure and earnings management, prior research offers three main assumptions in regards to this relationship. Relying on agency theory, the first strand of research finds that high disclosure quality can make investors better informed and as a result, managers' tendency to manipulate earnings will be constrained (see Riahi and Arab, 2011; Jo and Kim, 2007; Satya and Kuraesin, 2016). However, the second strand of research claims that high disclosure quality (particularly when it is based on forecasting activities) (Note 2) can also be one of the factors that motivate managers to manipulate earnings. This argument is in line with Hunton et al. (2006) and Iatridis and Kadorinis (2009), who reported that firms manage earnings to meet or beat the analyst forecast. In addition, Gong et al. (2009) also reported a significant positive association between management earnings forecasts and accrual, thus suggesting that managers manage earnings through accrual in meeting or beating earnings forecast. In contrast, Aerts and Cheng (2011) document that firms with high earnings management tend to release higher impression management disclosure when describing the firm's performance. These conflicting views in respect to disclosure quality and earnings management underline a prediction of a reciprocal relationship between these two variables (Zeibote, Volkova and Todorov, 2019).

\subsection{Disclosure Quality and Board Independence}

In regards to the relationship between disclosure quality and board independence, several studies demonstrated that there is a positive relationship between board independence and disclosure quality (e.g. Nelson et al., 2010; Kent and 
Stewart, 2008). Nevertheless, this finding is not "a one size fits all", which means it does not necessarily true in all situation. In this instance, reverse causality might occur when independent directors tend to join firms with high quality of disclosure because it portray that the firms are financially strong and less problematic.

In a different perspective, we can see that causality between disclosure quality and board independence can occur in the different direction. For example, according to Armstrong et al. (2010), external directors would be able to monitor the firms effectively in firms with high-disclosure environments, where they are supplied with timely and relevant information to perform their duties. This suggests that high disclosure environment is the main cause that influences the level of the independent director's effectiveness in a firm. Armstrong et al. (2010) also claim that independent directors who work in a firm with low quality information are not able to successfully perform their task due to lack of information provided to them.

\subsection{Board Independence and Earnings Management}

According to Kiel and Nicholson (2003), in line with agency theory perspective, the existence of external directors in the firms is expected to provide monitoring roles in combating earnings management activities in the firm's financial statement. However, previous studies reported conflicting findings in regards to this view. In this instance, Park and Shin (2004) and Kent et al. (2010) reported a non-significant relationship between board independence and earnings management.

Moreover, it is argued that there is a reverse causality in the relationship between board independence and earnings management. According to Armstrong et al. (2010), firms are ready to appoint external directors in the board when firms already committed to high standard of disclosure quality, and unlikely to involve in fraud activities. This suggests that when firms improved their level of disclosure quality and stay away from earnings management behaviour, only then they are willing to invite the external directors to the board.

Due to the possibility of reciprocal relationships between independent directors, earnings management and disclosure quality, we hypothesis that:

Hypothesis 1: There is a reciprocal relationship between earnings management, disclosure quality and board independence.

\section{Research Methodology}

\subsection{Sample and Data}

Our sample comprise of a matched-paired sample of 290 winners and non-winners of IR Magazine Award in the UK. We cover four years observation that is from the year 2005 to 2008. We rely on The IR Magazine Award Winners as to represent companies with high disclosure quality. The control sample in our study was selected based on the firms with the closest size, similar industry and year of annual report. In corroboration with Lehn et al. (2009) as well as Cornett et al. (2009), we developed the simultaneous system of equations and it will be estimated using 2 Stage Least Square Regression. We collected the data from the annual reports and databases such as Datastream and FAME.

\subsection{Determinants of Disclosure Quality, Board Independence and Earnings Management}

\section{Disclosure Quality Equation}

With respect to our disclosure quality equation, we note that several studies hypothesised that discretionary accruals (which is the proxy for earnings quality) and income smoothing as one of the important determinants for disclosure quality (Jans et al. 2005; Shaw, 2003).

Francis et al. (2008) demonstrated that there is a complementary relationship between earnings quality and disclosure quality, thus suggesting that firms with high earnings quality offer better disclosure quality than their counterparts. Furthermore, in their US study, Zhou and Lobo (2001) reported that there is negative reciprocal link between disclosure quality (measured using AIMR Ratings) and earnings management (estimated using the Modified Jones Model). Their finding implies that disclosure quality and earnings management are simultaneously related to each other.

We also include a number of board characteristics in our disclosure quality equation since previous studies reported that board characteristics are important in influencing disclosure quality. These include the number of board meeting in a year (Chen et al., 2006), board size (Bradbury et al., 2006), board independence (Klein, 2002); non-executive status of the chairman (Haniffa and Cooke, 2005), multiple directorship by chairman (Beasley, 1996) and tenure of chairman (Chen et al. 2006; Mabika, 2016). We also include substantial shareholders in our disclosure quality equation given that monitoring effect by substantial shareholders (Eng and Mak, 2003) is potentially useful in 
reducing conflict of interest in a firm, thus increasing high disclosure quality. Earnings variability is also include in the model since there is a negative relationship between earnings variability and voluntary disclosure reported by Francis et al. (2008).

In addition to board characteristics, prior literature also highlighted the significant effect of audit committee factors in influencing disclosure quality (Felo et al, 2003; Klein, 2002; Lin et al., 2006; O’Sullivan et al., 2008; Karamanao and Vafeas, 2005; Beasley, 1996). We therefore include several audit committee characteristics in our disclosure quality equation such as audit committee multiple directorship, audit committee size, audit committee independence, audit committee expertise, as well as audit committee meeting, in corroboration with prior studies in this field. We also control for several firm characteristics such as profitability (Singhvi and Desai, 1971; Debreceny and Rahman, 2005) firm size (Wallace and Naser, 1995), leverage (Wallace and Naser, 1995; Wallace et al., 1994; Raffournier, 1995; Hossain et al., 1994), analyst following (Chang et al., 2008), and audit quality (Raffournier, 1995; Inchausti, 1997). In line with Nelson et al. (2010), we also control for year and industry effects in our disclosure quality equation.

\section{Earnings Management Equation}

With respect to the earnings management equation, we incorporate disclosure quality as one of the determinants for earnings management since Jo and Kim (2007) point out that high disclosure quality will enhance the capabilities of investors and analysts in detecting earnings management, thus, reducing managers propensity to manage earnings. We also include board characteristics and audit committee characteristics in earnings management equation given that a strand of prior literature suggested that board meeting, board size, board independence, audit committee size, audit committee independence, audit committee expertise, and audit committee meeting are important in reducing managers tendency to manage earnings (e.g. Niu, 2006; Beasley, et al., 2009; García-Meca and Sánchez-Ballesta, 2010; Chtourou et al., 2001; Chang and Sun, 2009; Bedard et al., 2004; Zhong et al., 2007; Xie et al, 2003; Park and Shin, 2004; Cohen et al, 2004; Kiel and Nicholson, 2003; Pomeroy and Thornton, 2008; Klein, 2002; Zhao and Chen, 2008; Abbott et al. 2004).

We control for firm size in our earnings management equation since prior studies such as Lobo and Zhou (2006) as well and Zhau and Elder (2001) underlined that managers tendency to manage earnings might be lower in large firms since they are under high scrutiny from the investors. We include profitability in our equation (measured using lagged return on assets) in line with Skinner (2003), since it has a connection to the opportunity of investment by the firms. Lobo and Zhou (2006) claim that firms with high operating cash flow are unlikely to perform income-increasing earnings management since they are already achieving high performance. We control for loss firms given that Moreira and Pope (2007) claim that firms with negative earnings (LOSS) tend to manipulate earnings when compared to firms with positive earnings. In corroboration with Becker et al., (1998), the absolute value of total accruals is controlled in the equation since it is expected that high total accruals signifies high earnings management. We control for the number of analyst following since managers propensity to manage earnings is lower in the presence of financial analyst (Yu, 2008). Jo and Kim (2007) demonstrated that a change in performance is negatively and significantly related to earnings management at $\mathrm{p}<0.01$. We expect a positive relationship between investment opportunity and earnings management since Skinner (1993) opines that firms with high assets in place have greater tendency to manipulate earnings since they are stuck with high liabilities.

Several corporate characteristics such as audit quality, leverage, year effect and industry effect are also included in the earnings management following prior study in this area (e.g. Lapointe-Antunes et al., 2006; Ke, 2001; Kent et al. 2010; Bauer and Boritz, 2009; Jo and Kim, 2007; Habbash, 2010; Richardson et al., 2002; Becker et al., 1998).

\section{Board Independence Equation}

In regards to the board independence equation, in line with Lim et al. (2007) we includes board size since an increase in the board size will potentially improve or reduce the existence of independent directors in the board.

We include board ownership in board independent equation since Magena and Pike (2005) proposed that audit committee ownership influence the extent of audit committee independence. Positive relationship between number of blockholders and board independence is documented in Bhagat and Black (2002), thus we control for blockholders in this equation.

Director's remuneration is also incorporated in the equation since it has influence on the firm's outcome and a tool to motivate the managers (Doucouliagos et al. 2007) hence it is expected that remuneration is one of the mechanism to reflect the board independence in their decision making process. We include firm-specific business risk (PROFVAR) in this equation given that Demsetz and Lehn (1985) claim that monitoring in highly volatile firms is hard and this 
creates a risk of the moral hazard problem. It is argued that a high volatility of income (as a proxy for a firm's level of risk) could reduce board independence, given that such a situation is likely to induce agency conflict.

We include firm size in the equation, given that large firms can more easily afford to appoint a greater number of independent directors than small firms. Moreover, the complexities of business operation in large firms increase the necessity for more independent directors with a variety of knowledge and experience (Linck et al., 2008). High leverage (DTA) in a firm has potential to restrict the appointment of independent directors to the board (BODIND) due to a lack of cash. The percentage of independent directors on the board (BODIND) can also be influenced by the profitability of the firms (ROA), where more profitable firms can afford to employ more independent directors on the board. Growth is included since it has a significant effect to board independence (Bhagat and Black, 2002; Lehn et al., 2009; Coles et al., 2008).

Industry and year effects are also controlled in our board independence equation consistent with prior literature in this area (Beekes and Brown, 2006; Goodwin et al., 2009; Nelson et al., 2010).

\subsection{Model Presentation}

\subsubsection{Disclosure Quality, Board Independence and Earnings Management}

Assuming that three variables (earnings management, disclosure quality and board independence) are endogenously determined (H1), a simultaneous system of equations based on 2SLS estimation was used. The models are presented below:

(i) Earnings Management Equation:

MJONES = DQ + BODIND + BODSIZE + BODMEET + ACSIZE + ACIND + ACMEET + ACEXP + LOSS

+ DTA + ANALYST + TACF /LTA + NCF/LTA + PPE/LTA + BIG4 + LAGGEDROA + LMCAP + CHANGE

IN SALES + YEAR + INDUSTRY + e ---- [equation 1a]

(ii) Disclosure Quality Equation:

DQ $=$ BODIND + MJONES + BODSIZE + BODMEET + ACSIZE + ACMEET + ACIND + ACEXP + ACMULT + CHAIRTEN + CHAIRMULT + CHAIRNONEXE + SUBSHR + NOSUBSHR + ROA + DTA + BIG4 + ANALYST + EARNVAR + LMCAP + YEAR + INDUSTRY + e ---- [equation 1b].

(iii) Board independence equation:

BODIND = DQ + MJONES + BODSIZE + BODSHR + SUBSHR + NOSUBSHR + LREM + LOG MARKET

CAPITALISATION + DTA + ROA + MTBV + PROFVAR + YEAR + INDUSTRY + e ----- [equation 1c].

Where the variable definitions are as follows in Table 1:

Table 1. Variable definitions

\begin{tabular}{|c|c|c|}
\hline Labels & Variables & Definitions \\
\hline \multirow[t]{3}{*}{$\mathrm{DQ}$} & $\begin{array}{l}\text { Disclosure } \\
\text { Quality }\end{array}$ & $\begin{array}{l}\text { (a) IRAWARD = dummy [1 = winners of Investor Relation Award, } 0 \\
=\text { non-winners }]\end{array}$ \\
\hline & & $\begin{array}{l}\text { (b) FLSCORE = the number of forward-looking sentences in the } \\
\text { annual report }\end{array}$ \\
\hline & & (c) $\mathrm{AFA}=$ the analyst forecast accuracy \\
\hline MJONES & $\begin{array}{l}\text { Earnings } \\
\text { Management }\end{array}$ & Discretionary accrual estimated using Modified Jones Model \\
\hline ACMEET & $\begin{array}{l}\text { Audit committee } \\
\text { meeting }\end{array}$ & $1=$ if audit committee meetings $>=3,0=$ otherwise \\
\hline ACIND & $\begin{array}{l}\text { Audit committee } \\
\text { independence }\end{array}$ & $1=$ if independent members of audit committee $=100 \%, 0=$ otherwise \\
\hline ACSIZE & $\begin{array}{l}\text { Audit committee } \\
\text { size }\end{array}$ & $1=$ if audit committee members $>=3,0=$ otherwise \\
\hline ACEXP & $\begin{array}{l}\text { Audit committee } \\
\text { expertise }\end{array}$ & $1=$ if audit committee members with financial expertise $>=1,0=$ otherwise \\
\hline ACMULT & Audit committee & Average of audit committee directorship in other companies \\
\hline
\end{tabular}




\begin{tabular}{|c|c|c|}
\hline & $\begin{array}{l}\text { multiple } \\
\text { directorship }\end{array}$ & \\
\hline BODIND & $\begin{array}{l}\text { Board } \\
\text { independence }\end{array}$ & Percentage of independent directors on the board (excluding the chairman) \\
\hline BODSIZE & Board size & Total number of board members \\
\hline BODMEET & Board Meeting & Total number of board meetings in a year \\
\hline CHAIRTEN & Chairman tenure & Number of years a chairman can continue as chairman \\
\hline CHAIRNONEX & Chairman status & $1=$ if the chairman is a non-executive director, $0=$ otherwise \\
\hline CHAIRMULT & $\begin{array}{l}\text { Chairman } \\
\text { multiple } \\
\text { directorship }\end{array}$ & Average of chairman directorships in other companies \\
\hline SUBSHR & $\begin{array}{l}\text { Substantial } \\
\text { shareholding }\end{array}$ & $\begin{array}{l}\text { Total percentage of shareholding owned by substantial shareholders ( } 3 \% \\
\text { and above) }\end{array}$ \\
\hline NOSUBSHR & $\begin{array}{l}\text { Number of } \\
\text { substantial } \\
\text { shareholder }\end{array}$ & Total number of substantial shareholders who own $3 \%$ and above of shares \\
\hline LREM & $\begin{array}{l}\text { Total } \\
\text { remuneration }\end{array}$ & Natural log of total directors' remuneration \\
\hline LMCAP & $\begin{array}{l}\text { Market } \\
\text { capitalisation }\end{array}$ & Natural log of market capitalisation \\
\hline DTA & Debt to asset ratio & Total debt divided by total assets \\
\hline ROA & $\begin{array}{l}\text { Return on asset } \\
\text { ratio }\end{array}$ & Return on assets ratio \\
\hline LAGGED ROA & $\begin{array}{l}\text { Lagged return on } \\
\text { asset ratio }\end{array}$ & Lagged return on assets ratio \\
\hline CHGEINSALES & Change in Sales & Current year sales minus previous year sales divided by lagged total assets \\
\hline LOSS & LOSS & $1=$ if company making loss, $0=$ otherwise \\
\hline ANALYST & $\begin{array}{l}\text { Number of } \\
\text { analysts } \\
\text { following }\end{array}$ & Total number of analysts following \\
\hline BIG4 & Audit quality & $1=$ if firm is audited by a Big 4 audit firms, $0=$ otherwise \\
\hline BODSHR & Board share & Total percentage of board shareholding \\
\hline EARNVAR & $\begin{array}{l}\text { Earnings } \\
\text { variability }\end{array}$ & Standard deviation of operating income divided by sales \\
\hline PROFVAR & Profit variability & Standard deviation of return on assets \\
\hline YEAR & Year Dummies & $\begin{array}{l}\text { Dummies for the year 2007, } 2006 \text { and 2005. Year dummy for } 2004 \text { was } \\
\text { excluded. }\end{array}$ \\
\hline INDUSTRY & $\begin{array}{l}\text { Industry } \\
\text { Dummies }\end{array}$ & $\begin{array}{l}\text { Dummies for oil and gas, consumer goods, consumer services, healthcare, } \\
\text { telecommunications, utilities and technology. Industrial dummy was } \\
\text { excluded. }\end{array}$ \\
\hline $\mathrm{e}$ & Error term & Error term \\
\hline
\end{tabular}

\section{Findings}

\subsection{Descriptive Statistics and Pairwise Correlation}

The descriptive statistics and pairwise correlation have been performed but the results are not reported. The top and bottom $1 \%$ of all continuous variables had been winsorized to reduce the effect of outliers. We notice that none of the coefficient correlations are more than $80 \%$, and the variance inflation factors (VIF) are all below 10 hence indicates that there is no problem of multicollinearity. For the sake of brevity, we do not report the full results for descriptive statistics and pairwise correlation in the text, but they are available to the author upon request. 


\subsection{Co-determination Between Disclosure Quality, Earnings Management and Board Independence}

The co-determination tests were performed using 2SLS regression to detect a possible simultaneous relationship between disclosure quality, earnings management and board independence, and the results are presented in Table 2. Panel A of Table 2 employs IRAWARD as a proxy for disclosure quality, while Panel B and Panel C of Table 2 respectively employ FLSCORE and AFA to represent disclosure quality.

First and foremost, it can be observed that disclosure quality, earnings management and board independence are endogenously determined. By and large, Table 2 reveals that the results of 2SLS regression demonstrate significant reciprocal relationships between disclosure quality, earnings management and independent directors. Specifically, with regard to the first proxy for disclosure quality, IRAWARD (see Panel A, Table 2), results show that after controlling for the potential joint determination, a simultaneous relationship is reported between IRAWARD and MJONES, suggesting that the causality between IRAWARD and MJONES is reciprocal.

Correspondingly, (i) an increase in IRAWARD will reduce MJONES ( $\mathrm{p}<0.01$, coef $=-8.382$ ) and (ii) firms with high earnings management tend not to be selected as recipients of IRAWARD $(p<0.01$, coef $=-0.499)$. Moreover, a reciprocal relationship is also documented between BODIND and MJONES, with a significant negative result. In particular, the MJONES equation (Model 1, Panel A) signifies that BODIND is significant at $p<0.05$, coef $=-0.283$, while the BODIND equation (Model 3, Panel A) denotes a significant relationship between MJONES and BODIND at $\mathrm{p}<0.01$, coef $=-0.55$. This indicates that high disclosure quality restrains earnings management, and low earnings management results in an increased percentage of independent directors in a firm. Nonetheless, in contradiction of the hypothesis, no simultaneous relationship is found between BODIND and IRAWARD. The IRAWARD equation (Model 2, Panel A) shows that BODIND is negatively related to IRAWARD at $\mathrm{p}<0.01$, coef $=-0.132$, while the BODIND equation (Model 3, Panel A) reveals that IRAWARD is insignificant in influencing BODIND.

With regard to the second proxy for disclosure quality, FLSCORE, the results for 2SLS regressions are presented in Panel 2 (Table 2). Similar to the first proxy for disclosure quality discussed above, IRAWARD, a simultaneous relationship is also explicitly reported between FLSCORE and MJONES, suggesting that FLSCORE is important in reducing MJONES, and vice versa. However, the relationship between MJONES and BODIND is not pronounced given that BODIND is found to be insignificantly related to MJONES in the MJONES equation (Model 1, Panel B); however a significant association is shown between MJONES and BODIND in the BODIND equation (Model 3, Panel B). This finding indicates that higher earnings management decreases the percentage of independent directors on the board, signalling reverse causality. Concerning BODIND and FLSCORE, while previous results using IRAWARD indicate no simultaneous relationship, a positive reciprocal association is reported between FLSCORE and BODIND as seen in Models 2 and 3, Panel B of Table 2. Specifically, FLSCORE equation (Model 2, Panel B) documents a significant positive link between BODIND and FLSCORE at $\mathrm{p}<0.01$, while the BODIND equation (Model 3, Panel B) demonstrates that FLSCORE is positively related to BODIND at $p<0.01$. This finding is consistent with Gruning (2010) who reported a significant positive simultaneous relationship between sound corporate governance and disclosure quality.

In Panel $\mathrm{C}$ of Table 2, the third proxy for disclosure quality, AFA, is used. In line with the findings in IRAWARD and FLSCORE in Panel A and B, a negative reciprocal relationship between MJONES and AFA is reported, showing that causality runs in both directions. Analogous results are also reported for BODIND and MJONES, where a simultaneous negative relationship is reported, consistent with the findings in Panel A (where IRAWARD is employed as a proxy for disclosure quality). While Panel A reveals no simultaneous relationship between BODIND and IRAWARD and Panel B reports a positive reciprocal relationship between BODIND and FLSCORE, Panel C contradicts these results by showing a negative reciprocal relationship between BODIND and AFA. This indicates that a greater percentage of independent directors is associated with a decrease in the analyst forecast accuracy, while higher forecast accuracy decreases board independence. This finding, however, should be interpreted in the light of the caveats in this study. It is true that AFA is probably not a direct measure for disclosure quality; therefore it fails to capture the firm's overall disclosure quality, and leads to conflicting findings. In a related vein, the measurement for board independence using percentage of independent directors might not really portray the extent of board independence. The unresolved issue over defining bad and good governance is widely acknowledged (Brickey and Zimmerman, 2010). Moreover, Arcot and Bruno (2006) find that the firm's compliance with the corporate governance code in the UK is motivated merely by a "tick boxes" attitude, which "highlighted general conformity with the letter but not the spirit" (p. 35). In reality, some firms that apparently complied with the standard of corporate governance have also been involved in serious financial fraud (an example is Enron). 
Table 2 also reports that MJONES (Model 1, Panel A, B and C) is influenced not only by disclosure quality and board independence, but also by other determinants including ACSIZE, ACMEET, LNMCAP, PPE/LTA and TACF/LTA. A negative association is shown by ACSIZE at $p<0.1($ coef $=-2.76)$ and $p<0.05($ coef $=-3.57)$ when IRAWARD (Panel A) and AFA (Panel C) are interchangeably used as proxies for disclosure quality, while both OLS and 2SLS in the primary findings in part 1 reported insignificant linkage between ACSIZE and MJONES. Nonetheless, no significant relationship exists between ACSIZE and MJONES when FLSCORE is endogenised in the model. Consistent with the OLS findings and 2SLS regression in Part 1, ACMEET constantly reported a significant positive link to MJONES and this result is robust to which disclosure quality proxy is used in the simultaneous equation system. Similar results are also demonstrated for LMCAP and TACF/LTA, where both variables consistently revealed a positive association with MJONES regardless of the choice of disclosure quality proxy (see Model 1, Panels A, B and C). Healthcare companies more consistently record a positive relationship to earnings management than industrial companies (the industry dummy is excluded from the model), suggesting that earnings management is mainly engaged in by healthcare firms.

Regarding the determinants for disclosure quality (refer Model 2, Panel A, B and C), the respective models show mixed findings depending on the type of disclosure proxy used in the model. For example, ACSIZE is negatively related to disclosure quality in the IRAWARD and AFA models, but found to be insignificant in the FLSCORE model although a weak negative association is found. In other words, high ACSIZE reduces AFA and the likelihood of receiving an IRAWARD. This might be explained by the idea that large ACSIZE is not guaranteed to be always good in a firm given that it creates more opportunities for free-riders. This finding suggests a failure of corporate governance recommendations with respect to ACSIZE to enhance disclosure quality. In line with prediction, ACMEET is found to positively influence IRAWARD, FLSCORE and AFA - although only the first two are significant at $\mathrm{p}<0.01$, (coef $=6.146)$ and (coef $=0.0537)$ respectively. As a proxy for firm-level risk, EARNVAR shows an inverse association with IRAWARD and FLSCORE at $\mathrm{p}<0.05(\operatorname{coef}=-0.449)$ and $\mathrm{p}<0.1(\operatorname{coef}=-0.034)$ respectively, showing that increases in EARNVAR will result in lower FLSCORE and IRAWARD. In stark contrast, EARNVAR is revealed to be positively linked with AFA at $\mathrm{p}<0.05$ (coef $=0.163$ ). A positive association of BODMEET is reported in the IRAWARD, FLSCORE and AFA equations, although only the first two show a significant relationship. In a similar vein, high ACMULT and CHAIRMULT significantly increase IRAWARD and FLSCORE at $\mathrm{p}<0.01$ and $\mathrm{p}<0.05$ (for IRAWARD) and $\mathrm{p}<0.1$ and $\mathrm{p}<0.1$ (for FLSCORE) respectively. Contradicting the agency theory view, this finding suggests that directors having directorships in other companies increases disclosure quality.

In regards to the determinants of BODIND (refer Model 3 Panel A, B and C), BODSIZE reported a significant negative association with BODIND at $\mathrm{p}<0.05$ (coef $=-0.599$ ), signalling that firms with lower board independence will have a higher board size. This finding contradicts Lim et al. (2007) who report a positive association $(\mathrm{p}<0.1)$ between board size and board independence. While agency theory predicts that managerial compensation and director ownership will help to maintain board independence, LREM and BODSHR show an inverse relationship with BODIND at $\mathrm{p}<0.1$ (coef $=-1.67)$ and $\mathrm{p}<0.01$ (coef $=-0.158)$ respectively, revealing that lower director remuneration and lower board ownership are drivers for a more independent board. In addition, results also show that having a higher number of substantial shareholders (NOSUBSHR) increases the percentage of independent directors on the board at $\mathrm{p}<0.1$ (coef $=0.664$ ). PROFITVAR, which is a proxy for firm-level risk is also positively related to BODIND at $\mathrm{p}<0.01$ (coef $=2.10$ ). With regard to firm-specific characteristics, LMCAP is the only corporate characteristic found to be associated with BODIND in the model at $\mathrm{p}<0.01$. 
Table 2. 2SLS regression: disclosure quality, earnings management and board independence

\begin{tabular}{|c|c|c|c|c|c|c|c|c|c|}
\hline & \multicolumn{3}{|c|}{$\begin{array}{c}\text { PANEL A } \\
\text { DQ = IRAWARD }\end{array}$} & \multicolumn{3}{|c|}{$\begin{array}{c}\text { PANEL B } \\
\text { DQ = FLSCORE }\end{array}$} & \multicolumn{3}{|c|}{$\begin{array}{l}\text { PANEL C } \\
\mathrm{DQ}=\mathrm{AFA}\end{array}$} \\
\hline & \multirow{3}{*}{$\begin{array}{l}\text { MODEL1 } \\
\text { MJONES }\end{array}$} & \multirow{3}{*}{$\begin{array}{c}\text { MODEL2 } \\
\text { DQ(IRAWARD) }\end{array}$} & \multirow{3}{*}{$\begin{array}{c}\text { MODEL } \\
3 \\
\text { BODIND }\end{array}$} & \multirow{3}{*}{$\begin{array}{c}\text { MODEL } \\
1 \\
\text { MJONES }\end{array}$} & \multirow{3}{*}{$\begin{array}{c}\text { MODEL2 } \\
\text { DQ(FLSCORE) }\end{array}$} & \multirow{3}{*}{$\begin{array}{l}\text { MODEL3 } \\
\text { BODIND }\end{array}$} & \multirow{3}{*}{$\begin{array}{c}\text { MODEL } \\
1 \\
\text { MJONES }\end{array}$} & \multirow{3}{*}{$\begin{array}{l}\text { MODEL2 } \\
\text { DQ(AFA) }\end{array}$} & \multirow{3}{*}{$\begin{array}{l}\text { MODEL3 } \\
\text { BODIND }\end{array}$} \\
\hline & & & & & & & & & \\
\hline & & & & & & & & & \\
\hline \multicolumn{10}{|l|}{ Endogenous } \\
\hline \multicolumn{10}{|l|}{ Variables } \\
\hline \multirow[t]{2}{*}{ MJONES } & & $-0.499 * * *$ & $-0.55^{* * * *}$ & & $-0.018^{*}$ & $-0.46^{* * * *}$ & & $-0.269 * * *$ & $-1.512 * * *$ \\
\hline & & $(-5.13)$ & $(-3.05)$ & & $(-1.70)$ & $(-2.72)$ & & $(-4.36)$ & $(-6.69)$ \\
\hline \multirow{2}{*}{$\begin{array}{l}\text { DQ } \\
\text { (IRAWARD) }\end{array}$} & $-8.382 * * *$ & & -0.151 & & & & & & \\
\hline & $(-4.35)$ & & $(-0.06)$ & & & & & & \\
\hline \multirow[t]{2}{*}{ DQ (FLSCORE) } & & & & $-0.071^{* *} *$ & & $0.159 * * *$ & & & \\
\hline & & & & $(-2.16)$ & & $(6.35)$ & & & \\
\hline \multirow[t]{2}{*}{ DQ (AFA) } & & & & & & & $-5.58 * * *$ & & $-9.591 * * *$ \\
\hline & & & & & & & $(-8.62)$ & & $(-10.07)$ \\
\hline \multirow[t]{3}{*}{ BODIND } & $-0.283 * *$ & $-0.132 * *$ & & -0.176 & $0.0537 * * *$ & & $-0.568 * *$ & $-0.288 * * *$ & \\
\hline & $(-2.05)$ & $(-2.04)$ & & $(-1.50)$ & $(4.02)$ & & $*$ & $(-4.14)$ & \\
\hline & & & & & & & $(-6.39)$ & & \\
\hline \multicolumn{10}{|l|}{ Exogenous } \\
\hline \multicolumn{10}{|l|}{ Variables } \\
\hline \multirow[t]{2}{*}{ ACSIZE } & $-2.76^{*}$ & $-3.52 * * *$ & & -1.707 & -0.066 & & $-3.57 * *$ & $-1.132 * *$ & \\
\hline & $(-1.81)$ & $(-2.77)$ & & $(-0.97)$ & $(-0.42)$ & & $(-0.24)$ & $(-2.16)$ & \\
\hline \multirow[t]{2}{*}{ ACEXP } & 0.03 & -0.877 & & $2.07 *$ & 0.184 & & -1.94 & 0.11 & \\
\hline & $(0.03)$ & $(-1.11)$ & & (1.73) & $(1.38)$ & & $(-1.52)$ & $(0.30)$ & \\
\hline \multirow[t]{2}{*}{ ACMEET } & $8.525 * * *$ & $6.146 * * *$ & & $6.57 * * *$ & $0.32 * * *$ & & $2.63 *$ & 0.664 & \\
\hline & (4.66) & $(4.08)$ & & $(3.71)$ & $(2.63)$ & & $(1.80)$ & (1.45) & \\
\hline \multirow[t]{2}{*}{ ACIND } & -0.49 & -0.238 & & 1.21 & 0.177 & & $-1.35^{*}$ & -0.288 & \\
\hline & $(-0.49)$ & $(-0.34)$ & & $(0.92)$ & (1.59) & & $(-1.67)$ & $(-1.01)$ & \\
\hline \multirow[t]{2}{*}{ ACMULT } & & $0.3204 *$ & & & $0.037 *$ & & & 0.026 & \\
\hline & & $(1.71)$ & & & $(1.81)$ & & & $(0.49)$ & \\
\hline BODMEET & 0.138 & $0.175^{* *}$ & & 0.197 & $0.018^{* *}$ & & -0.036 & 0.017 & \\
\hline & $(1.21)$ & (2.10) & & $(1.56)$ & $(2.53)$ & & $(-0.43)$ & $(0.49)$ & \\
\hline BODSIZE & -0.161 & 0.008 & $-0.599 * *$ & 0.186 & $0.07 * * *$ & $-1.47 * * *$ & $-0.789 * *$ & $-0.355 * * *$ & $-1.472 * * *$ \\
\hline & $(-0.83)$ & $(0.08)$ & $(-2.17)$ & $(0.66)$ & (3.99) & $(-5.53)$ & $*$ & $(-4.05)$ & $(-6.09)$ \\
\hline & & & & & & & $(-5.55)$ & & \\
\hline CHAIRNONEX & & 0.282 & & & 0.075 & & & 0.287 & \\
\hline E & & $(0.51)$ & & & $(1.02)$ & & & $(0.98)$ & \\
\hline
\end{tabular}


Table 2 Continued

\begin{tabular}{|c|c|c|c|c|c|c|c|c|c|}
\hline & \multicolumn{3}{|c|}{$\begin{array}{c}\text { PANEL A } \\
\text { DQ = IRAWARD }\end{array}$} & \multicolumn{3}{|c|}{$\begin{array}{c}\text { PANEL B } \\
\text { DQ = FLSCORE }\end{array}$} & \multicolumn{3}{|c|}{$\begin{array}{l}\text { PANEL C } \\
\mathrm{DQ}=\mathrm{AFA}\end{array}$} \\
\hline & MODEL1 & MODEL2 & MODEL3 & MODEL1 & MODEL2 & MODEL3 & MODEL1 & MODEL2 & MODEL3 \\
\hline & MJONES & DQ(IRAWARD) & BODIND & MJONES & DQ(FLSCORE) & BODIND & MJONES & $\mathrm{DQ}(\mathrm{AFA})$ & BODIND \\
\hline \multirow[t]{2}{*}{ CHAIRTEN } & & $-0.1204 * * *$ & & & -0.001 & & & -0.02 & \\
\hline & & $(-2.87)$ & & & $(-0.23)$ & & & $(-1.27)$ & \\
\hline \multirow[t]{2}{*}{ CHAIRMULT } & & $0.27 * *$ & & & $0.026^{*}$ & & & 0.07 & \\
\hline & & $(2.23)$ & & & $(1.86)$ & & & $(1.54)$ & \\
\hline \multirow[t]{2}{*}{ SUBSHR } & & 0.0036 & -0.06 & & 0.001 & 0.012 & & -0.009 & -0.03 \\
\hline & & $(0.17)$ & $(-1.22)$ & & $(0.43)$ & $(0.28)$ & & $(-1.20)$ & $(-0.60)$ \\
\hline \multirow[t]{2}{*}{ NOSUBSHR } & & 0.167 & $0.664 \%$ & & -0.026 & 0.364 & & $0.143 * *$ & $0.604 *$ \\
\hline & & $(1.22)$ & $(1.74)$ & & $(-1.30)$ & $(1.03)$ & & $(2.55)$ & $(1.92)$ \\
\hline \multirow[t]{2}{*}{ PROFVAR } & & & $2.10 * * *$ & & & $1.97 * * *$ & & & $1.13 * *$ \\
\hline & & & $(4.63)$ & & & $(4.49)$ & & & $(2.61)$ \\
\hline \multirow[t]{2}{*}{ EARNVAR } & & $-0.449 * *$ & & & $-0.034 *$ & & & $0.163 * *$ & \\
\hline & & $(-2.25)$ & & & $(-1.71)$ & & & $(2.48)$ & \\
\hline \multirow[t]{2}{*}{ LREM } & & & $-1.67 *$ & & & $-2.44 * * *$ & & & -0.652 \\
\hline & & & $(-1.78)$ & & & $(-2.63)$ & & & $(-0.83)$ \\
\hline \multirow[t]{2}{*}{ BODSHR } & & & $-0.158 * * *$ & & & $-0.104 * * *$ & & & -0.066 \\
\hline & & & $(-2.85)$ & & & $(-2.86)$ & & & $(-1.20)$ \\
\hline \multicolumn{10}{|l|}{ Firm-specific } \\
\hline \multicolumn{10}{|l|}{ variables } \\
\hline \multirow[t]{2}{*}{ LNMCAP } & $2.18 * * *$ & $1.66^{* * * *}$ & $2.973 * * *$ & $1.608 * * *$ & $-0.89 * *$ & $1.86^{* * * *}$ & $3.801 * * *$ & $1.26 * * *$ & $7.43 * * *$ \\
\hline & $(4.32)$ & $(4.72)$ & $(4.34)$ & (3.22) & $(-2.04)$ & $(3.25)$ & $(7.66)$ & (5.01) & $(10.71)$ \\
\hline \multirow[t]{2}{*}{ ROA } & & $0.073 *$ & 0.08 & & -0.002 & 0.032 & & 0.019 & 0.09 \\
\hline & & $(1.90)$ & $(0.94)$ & & $(-0.48)$ & $(0.36)$ & & $(0.97)$ & $(1.05)$ \\
\hline \multirow[t]{2}{*}{ LAGGED ROA } & 0.07 & & & $0.07 *$ & & & $0.09 * * *$ & & \\
\hline & $(1.63)$ & & & $(1.80)$ & & & $(2.92)$ & & \\
\hline \multirow[t]{2}{*}{ DTA } & -0.005 & -0.011 & 0.02 & -0.001 & -0.001 & 0.024 & $-0.08 * * *$ & $-0.014 * *$ & $-0.164 * * *$ \\
\hline & $(-0.21)$ & $(-0.78)$ & $(0.55)$ & $(-0.05)$ & $(-0.47)$ & $(0.64)$ & $(-4.97)$ & $(-2.12)$ & $(-4.03)$ \\
\hline \multirow[t]{2}{*}{ CHGEINSALES } & -0.803 & & & $-0.98 *$ & & & -0.246 & & \\
\hline & $(-1.62)$ & & & $(-1.81)$ & & & $(-0.56)$ & & \\
\hline \multirow[t]{2}{*}{ MTBV } & & & -0.169 & & & $-0.147 * *$ & & & -0.1704 \\
\hline & & & $(-2.24)$ & & & $(-1.98)$ & & & $(-1.61)$ \\
\hline
\end{tabular}


Table 2. Continued

\begin{tabular}{|c|c|c|c|c|c|c|c|c|c|}
\hline & \multicolumn{3}{|c|}{$\begin{array}{c}\text { PANEL A } \\
\text { DQ = IRAWARD }\end{array}$} & \multicolumn{3}{|c|}{$\begin{array}{c}\text { PANEL B } \\
\text { DQ = FLSCORE }\end{array}$} & \multicolumn{3}{|c|}{$\begin{array}{l}\text { PANEL C } \\
\mathrm{DQ}=\mathrm{AFA}\end{array}$} \\
\hline & MODEL1 & MODEL2 & MODEL & MODEL1 & MODEL2 & MODEL & MODEL & MODEL2 & MODEL \\
\hline & MJONES & DQ(IRAWARD) & 3 & MJONES & DQ(FLSCORE) & 3 & 1 & $\mathrm{DQ}(\mathrm{AFA})$ & 3 \\
\hline & & & BODIND & & & BODIND & MJONES & & BODIND \\
\hline \multirow[t]{2}{*}{ PPE/LTA } & $-1.88 * *$ & & & $-1.424 *$ & & & -0.684 & & \\
\hline & $(-2.21)$ & & & $(-1.73)$ & & & $(-1.10)$ & & \\
\hline \multirow[t]{2}{*}{ NCF/LTA } & -0.888 & & & 0.23 & & & -3.9 & & \\
\hline & $(-0.17)$ & & & $(0.05)$ & & & $(-1.07)$ & & \\
\hline \multirow[t]{2}{*}{ ANALYST } & 0.129 & $0.14 * * *$ & & 0.035 & $0.008 *$ & & $0.09 * *$ & -0.005 & \\
\hline & $(1.47)$ & $(3.00)$ & & $(0.42)$ & $(1.69)$ & & $(2.02)$ & $(-0.27)$ & \\
\hline \multirow[t]{2}{*}{ TACF/LTA } & $36.37 * * *$ & & & $41.22 * * *$ & & & $21.16 * * *$ & & \\
\hline & $(3.28)$ & & & (3.90) & & & (2.99) & & \\
\hline \multirow[t]{2}{*}{ LOSS } & -0.745 & & & -1.309 & & & -0.525 & & \\
\hline & $(-0.50)$ & & & $(-0.79)$ & & & $(-0.38)$ & & \\
\hline \multirow{2}{*}{ BIG4 } & -4.157 & $-3.81 * *$ & & 0.04 & $0.446 * *$ & & 0.08 & 0.001 & \\
\hline & $(-1.55)$ & $(-2.55)$ & & $(0.02)$ & $(2.32)$ & & $(0.02)$ & $(0.00)$ & \\
\hline \multirow[t]{2}{*}{ YEAR 2007} & 0.716 & -0.596 & 1.31 & 1.62 & 0.08 & -1.59 & $2.93 * * *$ & 0.27 & $3.55 * *$ \\
\hline & $(0.70)$ & $(-1.01)$ & $(0.75)$ & $(1.43)$ & $(1.16)$ & $(-0.95)$ & $(3.60)$ & $(1.09)$ & $(2.34)$ \\
\hline \multirow[t]{2}{*}{ YEAR 2006} & 0.412 & -0.066 & 0.53 & $1.89 *$ & $0.219 * * *$ & $-3.379 * *$ & $1.83 * *$ & 0.26 & $2.83^{*}$ \\
\hline & $(0.48)$ & $(-0.12)$ & $(0.33)$ & (1.69) & (3.26) & $(-2.03)$ & $(2.48)$ & $(1.11)$ & $(1.92)$ \\
\hline \multirow[t]{2}{*}{ YEAR 2005} & -0.338 & -0.101 & 1.31 & -0.76 & -0.106 & 1.86 & -0.26 & 0.31 & -0.495 \\
\hline & $(-0.39)$ & $(-0.19)$ & $(0.77)$ & $(-0.87)$ & $(-1.32)$ & $(1.17)$ & $(-0.41)$ & $(0.91)$ & $(-0.31)$ \\
\hline \multirow[t]{2}{*}{ TECHNOLOGY } & -0.268 & 0.426 & 0.488 & -2.004 & $-0.285^{* * *}$ & 2.907 & 0.48 & 0.455 & 2.35 \\
\hline & $(-0.24)$ & $(0.62)$ & $(0.24)$ & $(-1.58)$ & $(-2.41)$ & $(1.46)$ & $(0.50)$ & (1.35) & $(1.46)$ \\
\hline \multirow[t]{3}{*}{ TELECOMMUNICATION } & -0.53 & -1.319 & -1.52 & 1.71 & 0.171 & -5.23 & $-27.07 * *$ & -2.44 & $-50.22 * *$ \\
\hline & $(-0.18)$ & $(-0.62)$ & $(-0.28)$ & $(0.53)$ & $(0.51)$ & $(-0.90)$ & $*$ & $(-1.27)$ & $*$ \\
\hline & & & & & & & $(-5.96)$ & & $(-5.35)$ \\
\hline \multirow[t]{2}{*}{ CONSUMERGOODS } & -0.817 & -0.882 & 0.76 & $-1.77 *$ & $-0.284 * * *$ & $3.71 * *$ & $-1.693 *$ & 0.118 & $-3.35 *$ \\
\hline & $(-0.93)$ & $(-1.10)$ & $(0.39)$ & $(-1.70)$ & $(-2.64)$ & $(2.04)$ & $(-1.79)$ & $(0.32)$ & $(-1.67)$ \\
\hline \multirow[t]{2}{*}{ CONSUMERSERVICES } & 0.633 & -0.661 & 2.55 & 0.32 & $-0.287 * * *$ & $5.82 * * *$ & $2.83^{* * * *}$ & $1.058 * * *$ & $5.23 * * *$ \\
\hline & $(0.78)$ & $(-1.10)$ & $(1.46)$ & $(0.33)$ & $(-3.30)$ & $(3.56)$ & $(4.46)$ & (3.13) & $(4.12)$ \\
\hline \multirow[t]{3}{*}{ HEALTHCARE } & $17.401 * * *$ & $9.56 * * *$ & $9.21 * *$ & $21.91 * * *$ & $0.557 * *$ & -0.317 & $19.006 * *$ & $6.15 * * *$ & $29.23 * * *$ \\
\hline & $(4.52)$ & $(4.41)$ & $(2.36)$ & $(4.45)$ & (2.49) & $(-0.08)$ & $*$ & (3.75) & $(5.43)$ \\
\hline & & & & & & & $(5.52)$ & & \\
\hline \multirow[t]{3}{*}{ UTILITIES } & $-2.298 * *$ & $-3.706 * * *$ & -1.41 & 1.42 & $0.172 *$ & $-6.548 * *$ & $1.895 * *$ & 0.16 & 1.379 \\
\hline & $(-2.19)$ & $(-3.48)$ & $(-0.51)$ & $(0.96)$ & $(1.80)$ & $*$ & $(2.16)$ & $(0.31)$ & $(0.45)$ \\
\hline & & & & & & $(-2.71)$ & & & \\
\hline \multirow[t]{2}{*}{ OIL AND GAS } & -1.51 & $-2.296 * * *$ & 1.91 & 1.99 & 0.08 & $-3.68 *$ & $-1.48 * *$ & 0.066 & -2.439 \\
\hline & $(-1.21)$ & $(-2.71)$ & $(0.97)$ & $(1.25)$ & $(0.86)$ & $(-1.86)$ & $(-2.03)$ & $(0.17)$ & $(-1.39)$ \\
\hline \multirow[t]{2}{*}{ _cons } & -10.87 & $-16.61 * * *$ & $42.5 * * *$ & $-16.36 *$ & 0.886 & $62.35 * * *$ & $-14.36^{* * *}$ & 0.98 & $-31.37 * *$ \\
\hline & $(-1.33)$ & $(-3.88)$ & (3.16) & $(-1.89)$ & $(1.58)$ & $(5.06)$ & $(-2.16)$ & $(0.47)$ & $(-2.34)$ \\
\hline $\mathrm{N}$ & 290 & 290 & 290 & 290 & 290 & 290 & 254 & 254 & 254 \\
\hline F-stat/ LR Chi ${ }^{2}$ & 5.61 & 205.97 & 4.26 & 5.04 & 670.45 & 7.88 & 7.99 & 2.91 & 10.78 \\
\hline $\mathrm{p}$ & 0.000 & 0.000 & 0.000 & 0.000 & 0.000 & 0.000 & 0.000 & 0.000 & 0.000 \\
\hline R-sq/ pseudo $r^{2}$ & 0.5641 & 0.5123 & 0.2306 & 0.5361 & 0.4795 & 0.3335 & 0.7201 & 0.1806 & 0.4684 \\
\hline
\end{tabular}

Note: Figures in non-parentheses are the coefficients, while figures in parentheses are the t-statistics. $* * *, * *$ and $*$ indicate level of significance at $\mathrm{p}<0.01, \mathrm{p}<0.05$ and $\mathrm{p}<0.1$ respectively. 


\section{Summary of findings (2SLS regression)}

\begin{tabular}{llll}
\hline Disclosure Quality & \multicolumn{1}{c}{ Endogenous } & \multicolumn{1}{c}{ Results } & Hypothesis (Supported/ Not supported) \\
\hline IRAWARD & $\begin{array}{l}\text { IRAWARD \& } \\
\text { MJONES }\end{array}$ & Reciprocal relationship (-) & Supported \\
& $\begin{array}{l}\text { BODIND \& } \\
\text { MJONES }\end{array}$ & Reciprocal relationship (-) & Supported \\
& $\begin{array}{l}\text { BODIND \& } \\
\text { IRAWARD }\end{array}$ & $\begin{array}{l}\text { No reciprocal relationship. } \\
\text { One-way causality is } \\
\text { reported. }\end{array}$ & Not supported \\
\hline FLSCORE & FLSCORE \& & $\begin{array}{l}\text { Reciprocal } \\
\text { relationship (-) }\end{array}$ & Supported \\
& MJONES & $\begin{array}{l}\text { No reciprocal relationship. } \\
\text { Reverse causality found. }\end{array}$ & Not supported \\
\hline BODIND \& & $\begin{array}{l}\text { Reciprocal } \\
\text { relationship (+) }\end{array}$ & Supported \\
\hline MJONES & BODIND \& & Supported \\
\hline FLSCORE & reciprocal & Supported \\
\hline AFA & BFA MJONES & Reciprocal (-) \\
relationship (-) & $\begin{array}{l}\text { Reciprocal } \\
\text { relationship (-) }\end{array}$ & Supported \\
\hline
\end{tabular}

\subsection{Additional Tests}

Besides using 2SLS regression, all of the joint determination tests between disclosure quality, earnings management and board independence was also conducted using three-stage least square (3SLS) regression (the reg3 command) in STATA (for the sake of brevity, full results not reported). Some studies employ 3SLS regression in joint determination tests (e.g. Toledo, 2010; Gruning, 2010; Zhu, 2009), while Bhagat and Brian (2008) employ OLS, 2SLS and 3SLS estimation in their studies. According to Bhagat and Brian (2008), 2SLS estimation "allow[s] for potential endogeneity" while 3SLS estimation "allow[s] for potential endogeneity and cross-correlation between the equations" (p. 264). Our results using the reg3 command reveal that the findings reported in this study are largely unaffected; hence it is reasonable to conclude that the results are robust across other estimations as well. Another issue is that because both SUBSHR and NOSUBSHR are always located in the same model, these proxies are potentially measuring the same thing. As an additional test, another 2SLS regression was performed employing SUBSHR and NOSUBSHR interchangeably, and the results were largely unaffected by this change.

\subsection{Conclusions}

Disclosure quality, earnings management and board independence are found to be endogenously determined. Results from simultaneous equation regression demonstrate significant relationships between disclosure quality, earnings management and independent directors. High disclosure quality reduces earnings management activity, and low earnings management results in an increased percentage of independent directors in a firm.

After taking into account the possibility of co-determination, the findings demonstrate a negative reciprocal relationship between MJONES and DQ. This result is robust across all disclosure quality proxies (i.e., IRAWARD, FLSCORE and AFA).

A negative relationship is also documented between MJONES and BODIND, and the causality runs in both directions in Panels A and C (where IRAWARD and AFA are used as a proxy for disclosure quality). Nonetheless, only a one-way relationship appears between MJONES and BODIND when FLSCORE is used as a proxy for disclosure quality, as a result of an insignificant link between BODIND and MJONES in the MJONES equation.

The findings reveal that the interactions between all disclosure quality proxies and BODIND are mixed. When IRAWARD is used as a proxy for disclosure quality, no reciprocal relationship is seen between BODIND and IRAWARD. However, when FLSCORE and AFA are employed as proxies for disclosure quality, significant positive and negative associations are reported with board independence, with a reciprocal relationship. Hence, the simultaneous association between DQ and BODIND varies depending on which proxy for disclosure quality is used in the analysis. Moreover, it appears that BODIND is more useful in reducing MJONES than other internal 
governance mechanisms (such as audit committee characteristics) that show a weak effect on curbing earnings management.

Overall, from the theoretical viewpoint, our finding provides indirect evidence on the incentives that affect managerial disclosure. Disclosure quality outperformed corporate governance in mitigating earnings management; this supports the view that managerial disclosure is aimed at reducing information asymmetry. Although some of the corporate governance mechanisms have a similar effect to disclosure quality in reducing earnings management, independent directors exhibit a greater ability to fulfil complementary roles in the overall governance system.

\section{References}

Abbott, L.J., Parker, S., \& Peters, G.F. (2004). Audit committee characteristics and restatements. Auditing: A Journal of Practice \& Theory, 23(1), 69-87.

Adam, R., \& Ferreira, D. (2007). A theory of friendly boards. Journal of Finance, 62, 217-250.

Aerts, W., \& Cheng, P. (2011). Causal disclosures on earnings and earnings management in an IPO setting. Journal of Accounting and Public Policy, 30(5), 431-459.

Agrawal, A., \& Knoeber, C.R. (1996). Firm performance and mechanisms to control agency problems between managers and shareholders. Journal of Financial and Quantitative Analysis, 31(3), 377-397.

Ahmed, K., \& Courtis, J.K. (1999). Associations between corporate characteristics an disclosure levels in annual reports: A meta-analysis. British Accounting Review, 31, 35-61.

Ajinkya, B., Bhojraj, S., \& Sengupta, P. (2005). The association between outside directors, institutional investors and the properties of management earnings forecast. Journal of Accounting Research, 43(3), 343-376.

Albasu, J., \& Nyameh, J. (2017). Relevance of stakeholders theory, organizational identity theory and social exchange theory to corporate social responsibility and employees performance in the commercial banks in Nigeria. International Journal of Business, Economics and Management, 4(5), 95-105.

Ashraf, M., Shafiq, A., \& Batool, S. (2017). China Pakistan Economic Corridor (CPEC): Analysis of Internal and External Challenges. International Journal of Business, Economics and Management, 4(5), 106-111.

Arcot, S., \& Bruno, V. (2006). In letter but not in spirit: An analysis of corporate governance in the UK. Working Paper, London School of Economics.

Armstrong, C.S., Guay, W.R., \& Weber, J.P. (2010). The role of information and financial reporting in corporate governance and debt contracting. Journal of Accounting and Economics, 50(2-3), 179-234. https://doi.org/10.1016/j.jacceco.2010.10.001

Baek, H.Y., Johnson, D.R., \& Kim, J.W. (2009). Managerial ownership, corporate governance and voluntary disclosure. Journal of Business \& Economic Studies, 15(2), 44-61.

Bamber, L.S., Jiang, J.X., \& Wang, I.Y. (2010). What's my style? The influence of top managers on voluntary corporate financial disclosure. The Accounting Review, 85(4), 1131-1162.

Bauer, T., \& Boritz, J.E. (2009). Corporate reporting awards and financial reporting quality. Working Paper, University of Waterloo.

Beasley, M. (1996). An empirical analysis of the relation between the board of director composition and financial statement fraud. The Accounting Review, 71(4), 443-65.

Beasley, M., Carcello, J., Hermanson, D., \& Neal, T. (2009). The audit committee oversight process. Contemporary Accounting Research, 26(1), 65-122.

Becker, C., DeFond, M., Jiambalvo, J., \& Subramanyam, K.R. (1998). The effects of audit quality on earnings management. Contemporary Accounting Research, 15(1), 1-24.

Bédard, J., Chtourou, S.M., \& Courteau, L. (2004). The effect of audit committee expertise, independence, and activity on aggressive earnings management. Auditing: A Journal of Practice \& Theory, 23(2), 13-35.

Beekes, W., \& Brown, P. (2006). Do better-governed Australian firms make more informative disclosures?. Journal of Business Finance \& Accounting, 33(3-4), 422-450.

Berger, P.G. (2011). Challenges and opportunities in disclosure research-A discussion of "the financial reporting environment: Review of the recent literature." Journal of Accounting and Economics, 51(1-2), 204-218. https://doi.org/10.1016/j.jacceco.2011.01.001

Beyer, A., Cohen, D.A., Lys, T,Z., \& Walther, B.R. (2010). The financial reporting environment: Review of the recent literature. Journal of Accounting and Economics, 50, 296-543.

Bhagat, S., \& Black, B.S. (2002). The non-correlation between board independence and long-term firm performance. Journal of Corporation Law, 27, 231-273.

Bhagat, S., \& Brian, B. (2008). Corporate governance and firm performance. Journal of Corporate Finance, 14 , $257-273$

Boone, A., Field, L., Karpoff, J., \& Raheja, C. (2007). The determinants of corporate board size and composition: an empirical analysis. Journal of Financial Economics, 85, 66-101. 
Botosan, C.A. (1997, July). Disclosure level and cost of equity capital. The Accounting Review, 323-349.

Botosan, C.A., \& Stanford, M. (2005). Managers' motives to withhold segment disclosures and the effect of SFAS No. 131 on analysts' information environment. The Accounting Review, 80(3), 751-771.

Bradbury, M., Mak, Y., \& Tan, S. (2006). Board characteristics, audit committee characteristics and abnormal accruals. Pacific Accounting Review, 18, 47-68.

Brick, I.E., Palia, D., \& Wang, C. (2008). The joint impact of corporate governance mechanisms on firm performance and each other. Working paper, Rutgers University.

Brickley, J.A., \& Zimmerman, J.L. (2010). Corporate governance myths: Comments on Armstrong, Guay, and Weber. Journal of Accounting and Economics, 50(2-3), 235-245. https://doi.org/10.1016/j.jacceco.2010.10.002

Brockman, P., Martin, X., \& Puckett, A. (2011). Voluntary disclosures and exercise of CEO stock options. Journal of Corporate Finance, 16, 120-136.

Brown, P., Beekes, W., \& Verhoeven, P. (2011). Corporate governance, accounting and finance: A review. Accounting \& Finance, 51(September 2010), 96-172.

Call, A.C., Chau, S., Miao, B., \& Tong, Y.H. (2010). Do firms issuing short-term earnings guidance exhibit worse earnings quality?. Working Paper, University of Georgia.

Chang, J.C., \& Sun, H.L. (2009). Crossed-listed foreign firms' earnings informativeness, earnings management and disclosures of corporate governance information under SOX. The International Journal of Accounting, 44, 1-32.

Chang, M., D’Anna, G., Watson, I., \& Wee, M. (2008). Does disclosure quality via investor relations affect information asymmetry?. Australian Journal of Management, 33(2), 375-390.

Chen, C.J.P., \& Jaggi, B. (2000). Association between independent non-executive directors, family control and financial disclosures in Hong Kong. Journal of Accounting and Public Policy, 19, 285-310.

Chen, G., Firth, M., Gao, D.N., \& Rui, O.M. (2006). Ownership structure, corporate governance, and fraud: Evidence from China. Journal of Corporate Finance, 12, 424-448.

Chenhall, R.H., \& Moers, F. (2007). The issue of endogeneity within theory-based, quantitative management accounting research. European Accounting Review, 16(1), 173-195.

Chow, C.W., \& Wong-Boren, A. (1987). Voluntary financial disclosure by Mexican corporations. The Accounting Review, 62(3), 533-541.

Chtourou, S.M., Bedard, J., \& Courteau, L. (2001). Corporate governance and earnings management. Working Paper, University Laval, Canada.

Clinch, G., \& Verrecchia, R. (2011). Endogenous disclosure choice. Working paper, University of Melbourne.

Cohen, J., Krishnamoorthy, G., \& Wright, A. (2004). The corporate governance mosaic and financial reporting quality. Journal of Accounting Literature, 23, 87-148.

Coles, J.L., Daniel, N.D., \& Naveen, L. (2008). Boards: Does one size fit all?. Journal of Financial Economics, 87, 329-356.

Conyon, M., Mallin, C., \& Sadler, G. (2002). The disclosure of directors' share option information in UK companies. Applied Financial Economics, 12, 95-103.

Cornett, M.M., McNutt, J.J., \& Tehranian, H. (2009). Corporate governance and earnings management at large U.S. bank holding companies. Journal of Corporate Finance, 15(4), 412-430. https://doi.org/10.1016/j.jcorpfin.2009.04.003

Davidson, W.N., Jiraporn, P., Kim, Y.S., \& Nemec, C. (2004). Earnings management following duality-creating successions: Ethnostatistics, impression management and agency theory. Academy of Management Journal, 47(2), 267-275.

Debreceny, R., \& Rahman, A. (2005). Firm specific determinants of continuous corporate disclosures. The International Journal of Accounting, 40, 249-278.

Demsetz, H., \& Lehn, K. (1985). The structure of corporate ownership causes and consequences. Journal of Political Economy, 93, 1155-1177.

Donnelly, R., \& Mulcahy, M. (2008). Board structure, ownership and voluntary disclosure in Ireland. Corporate Governance: The International Review, 16, 416-429.

Doucouliagos, H., Haman, J., \& Askary, S. (2007). Directors' remuneration and performance in Australian banking. Corporate Governance: The International Review, 15, 1363-1382.

Eng, L.L., \& Mak, Y.T. (2003). Corporate governance and voluntary disclosure. Journal of Accounting and Public Policy, 22, 325-345.

Ertimur, Y. (2004). Accounting numbers and information asymmetry: Evidence from loss firms. Working Paper, Duke University.

Felo, A.J., Krishnamurthy, S., \& Solieri, S.A. (2003). Audit committee characteristics and the perceived quality of financial reporting: An empirical analysis. Working Paper. https://doi.org/10.2139/ssrn.401240

Francis, J., Nanda, D., \& Olsson, P. (2008). Voluntary disclosure, earnings quality and cost of capital. Journal of Accounting Research, 46(1), 53-99. 
García-Meca, E., \& Sánchez-Ballesta, J.P. (2010). The association of board independence and ownership concentration with voluntary disclosure: A meta- analysis. European Accounting Review, 19, 603-627.

Gavious, I. (2007). Market reaction to earnings management: The incremental contribution of analysts. International Research Journal of Finance and Economics, 8, 196-214.

Glosten, L., \& Milgrom, P. (1985, March). Bid, ask, and transaction prices in a specialist market with heterogeneously informed traders. Journal of Financial Economics, 26, 71-100.

Gong, G., Yue Li, L., \& Xie, H. (2009). The association between management earnings forecast errors and accruals. The Accounting Review, 84(2), 497-530.

Goodwin, J., Ahmed, K., \& Heaney, R. (2009). Corporate governance and the prediction of the impact of AIFRS adoption. Abacus, 45(1), 124-145. https://doi.org/10.1111/j.1467-6281.2008.00271.x

Gruning, M. (2010). The association between disclosure and corporate governance, Paper presented at European Accounting Association Congress, 2010 Istanbul.

Habbash, M. (2010). The effectiveness of corporate governance and external audit on constraining earnings management practice in the UK. Durham Thesis, Durham University.

Haniffa, R.M., \& Cooke, T.E. (2002). Culture, corporate governance and disclosure in Malaysian corporations. Abacus, 38(3), 317-349. https://doi.org/10.1111/1467-6281.00112

Haniffa, R.M., \& Cooke, T.E. (2005). The impact of culture and governance on corporate social reporting. Journal of Accounting and Public Policy, 24, 391-430.

Harris, M., \& Raviv, A. (2008). A theory of board control and size. Review of Financial Studies, 21, 1797-1832.

Holm, C., \& Schøler, F. (2010). Reduction of asymmetric information through corporate governance mechanism the importance of ownership dispersion and exposure toward the international capital market. Corporate Governance: An International Review, 18(1), 32-47.

Hossain, M., Tan, L.M., \& Adams, M. (1994). Voluntary disclosure in an emerging capital market: Some empirical evidence from companies listed on the Kuala Lumpur Stock Exchange. The International Journal of Accounting, 29(4), 334-351.

Hunton, J., Libby, R., \& Mazza, C. (2006). Financial reporting transparency and earnings management. The Accounting Review, 81(1), 135-157.

Hussain, H.I., Ali, A., Thaker, H.M.T., \& Ali, M. (2019). Firm Performance and Family Related Directors: Empirical Evidence from an Emerging Market. Contemporary Economics, 13(2), 187-204.

Iatridis, G., \& Kadorinis, G. (2009). Earnings management and firm financial motives: A financial investigation of UK listed firms. International Review of Financial Analysis, 18(4), 164-173. https://doi.org/10.1016/j.irfa.2009.06.001

Inchausti, B.G. (1997). The influence of company characteristics and accounting regulation on information disclosed by Spanish firms. The European Accounting Review, 6(1), 45-68.

Jans, M., Orens, R., \& Lybaert, N. (2005). The relation between disclosure quality, income smoothing and earnings timeliness. Working Paper.

Jalloh, M., \& Guevera, Y. (2017). Financial deepening, interest rate spread and economic growth: New evidence from Sub-Sahara Africa. International Journal of Business, Economics and Management, 4(3), 52-64.

Jo, H., \& Kim, Y. (2007). Disclosure frequency and earnings management. Journal of Financial Economics, 84(2), 561-590. https://doi.org/10.1016/j.jfineco.2006.03.007

Karamanou, I., \& Vafeas, N. (2005). The association between corporate boards, audit committees, and management earnings forecasts: An empirical analysis. Journal of Accounting Research, 43(3), 453-485.

$\mathrm{Ke}$, B. (2001). Why do CEOs of publicly traded firms prefer reporting small increases in earnings and long strings of consecutive earnings increases?. Working Paper, The Pennsylvania State University.

Kheyfets, B.A., \& Chernova, V.Y. (2019). Sustainable agriculture in Russia: research on the dynamics of innovation activity and labor productivity. Entrepreneurship and Sustainability Issues, 7(2), 814-824.

Kent, P., Routledge, J., \& Stewart, J. (2010). Innate and discretionary accruals quality and corporate governance. Journal of Accounting and Finance, 50, 171-195.

Kent, P., \& Stewart, J. (2008). Corporate governance and disclosures on the transition to International Financial Reporting Standards. Journal of Accounting \& Finance, 48, 649-671.

Kiel, G., \& Nicholson, G. (2003). Board composition and corporate performance: How the Australian experience informs contrasting theories of corporate governance. Corporate Governance, 11(3), 189-205.

Kimbrough, M., \& Louis, H. (2011). Voluntary disclosure to influence investor reactions to merger announcements: An examination of conference calls. The Accounting Review, 86(2), 637-667.

Klein, A. (2002). Audit committee, board of director characteristics, and earnings management. Journal of Accounting and Economics, 33(3), 375-400.

Lang, M., Lins, K., \& Maffett, M. (2011). Transparency, liquidity and valuation: International evidence, University of North Carolina at Chapel Hill. Working Paper. 
Lang, M., \& Lundholm, R. (2000). Voluntary disclosure and equity offerings: reducing information asymmetry or hyping the stock?. Contemporary Accounting Research, 17(4), 623-62.

Lapointe-Antunes, P., Cormier, D., Magnan, M., \& Gay-Angers, S. (2006). On the relationship between voluntary disclosure, earnings smoothing and the value relevance of earnings: The case of Switzerland. European Accounting Review, 15(4), 465-505.

Lehn, K.M., Patro, S., \& Zhao, M. (2009). Determinants of the size and composition of US corporate boards. Financial Management, 38(4), 747-780. https://doi.org/10.1111/j.1755-053X.2009.01055.x

Lent, L.V. (2007). Endogeneity in management accounting research: A comment. European Accounting Review, 16(1), 197-205.

Leuz, C., Nanda, D., \& Wysocki, P.D. (2003). Earnings management and investor protection: an international comparison. Journal of Financial Economics, 69(3), 505-527. https://doi.org/10.1016/S0304-405X(03)00121-1

Li, J., Pike, R., \& Haniffa, R. (2008). Intellectual capital disclosure and corporate governance structure in UK firms. Accounting and Business Research, 38(2), 137-159. https://doi.org/10.1080/00014788.2008.9663326

Lim. S., Matolcsy, Z., \& Chow, D. (2007). The association between board composition and different types of voluntary disclosure. European Accounting Review, 16(3), 555-583.

Lin, J., Li, J., \& Yang, J. (2006). The effect of audit committee performance on earnings quality. Managerial Auditing Journal, 21(9), 921-33.

Linck, J.S., Netter, J.M., \& Yang, T. (2008). The determinants of board structure. Journal of Financial Economics, 87(2), 308-328.

Lobo, G., \& Zhou, J. (2006). Did conservatism in financial reporting increase after the Sarbanes-Oxley Act? Initial evidence. Accounting Horizons, 20, 57-73.

Magena, M., \& Pike, R. (2005). The effect of audit committee shareholding, financial expertise and size on interim financial disclosure. Accounting and Business Research, 35(4), 327-349.

Mabika, H. (2016). The Human Capital Retention Strategies that Local Authorities in Zimbabwe Can Adopt for Successful Talent Retention. International Journal of Management and Sustainability, 5(3), 17-22.

Marston, C. (2008). Investor relation meetings: Evidence from the top 500 UK companies. Accounting and Business Research, 38(1), 21-48.

Moreira, J.A.C., \& Pope, P.F. (2007). Earnings management to avoid losses: A cost of debt explained. Working Paper, University of Oporto.

Myers, S., \& Majluf, N. (1984). Corporate financing and investment decision when firms have information that investors do not have. Journal of Financial Economics, 13, 187-221.

Nelson, J., Gallery, G., \& Percy, M. (2010). Role of corporate governance in mitigating the selective disclosure of executive stock option information. Accounting \& Finance, 50(3), 685-717.

Niu, F.F. (2006). Corporate governance and the quality of accounting earnings: a Canadian Perspective. International Journal of Managerial Finance, 2(4), 302-327.

Okon, E.O. (2016). Business Development in Nasarawa State: Effect of Poor Sanitation and Waste Management System. International Journal of Economics, Business and Management Studies, 3(1), 36-46.

O'Sullivan, M., Percy, M., \& Stewart, J. (2008). Australian evidence on corporate governance attributes and their associations with forward-looking information in the annual report. Journal of Management and Governance, $12(1), 5-35$.

Park, Y.W., \& Shin, H.H. (2004). Board composition and earnings management in Canada. Journal of Corporate Finance, 10(3), 431-457.

Patelli, L., \& Prencipe, A. (2007). The relationship between voluntary disclosure and independent directors in the presence of dominant shareholder. European Accounting Review, 16(1), 5-33.

Peterson, C., \& Plenborg, T. (2006). Voluntary disclosure and information asymmetry in Denmark. Journal of International Accounting, Auditing and Taxation, 15, 127-149.

Pomeroy, B., \& Thornton, D.B. (2008). Meta-analysis and the accounting literature: The case of audit committee independence and financial reporting quality. European Accounting Review, 17(2), 305-30.

Raffournier, B. (1995). The determinants of voluntary financial disclosure by Swiss listed companies. The European Accounting Review, 4(2), 261-280.

Riahi, Y., \& Arab, M.B.E.N. (2011). Disclosure frequency and earnings management: An analysis in the Tunisian context. Journal of Accounting and Taxation, 3(3), 47-59.

Richardson, S., Tuna, A.I., \& Wu, M. (2002). Predicting earnings management: The case of earnings restatements, (October). Working paper.

Richardson, V. (2000). Information and earnings management: Some evidence. Review of Quantitative Finance and Accounting, 15(4), 325-347.

Satya, M.T., \& Kuraesin, A. (2016). Analysis Place Branding as a Local Culture Kampung Naga West Java Indonesia. International Journal of Management and Sustainability, 5(2), 11-16. 
Shaw, K.W. (2003). Corporate disclosure quality, earnings smoothing, and earnings' timeliness. Journal of Business Research, 56, 1043-1050.

Sheng, C. (2019). Research of Entrepreneurial Candidate: Exploring Motivation and Prospective Technological Innovation in Singapore. American Journal of Social Sciences and Humanities, 4(1), 210-221.

Shleifer, A., \& Vishny, R.W. (1997). A survey of corporate governance. The Journal of Finance, 52(2), 737-783.

Singhvi, S., \& Desai, H.B. (1971). An empirical analysis of the quality of corporate financial disclosure. The Accounting Review, 46(1), 129-138.

Skinner, D.J. (1993). The investment opportunity set and accounting procedure choice. Journal of Accounting and Economics, 16, 407-445.

Skinner, D.J. (2003). Should firms disclose everything to everybody? A discussion of "Open vs. closed conference calls: the determinants and effects of broadening access to disclosure". Journal of Accounting and Economics, 34, 181-187.

Toledo, E.P. (2010). The relationship between corporate governance and firm value: A Simultaneous equations approach for analyzing the case of Spain. Working Paper.

Trueman, B., \& Titman, S. (1988). An explanation for accounting income smoothing. Journal of Accounting Research, 26, Supplement, 127-139.

Vafeas, N. (1999). Board meeting frequency and firm performance. Journal of Financial Economics, 53, 113-142.

Vafeas, N. (2005). Audit committees, boards, and the quality of reported earnings. Contemporary Accounting Research, 22(4), 1093-1122.

Verrecchia, R.E., \& Weber, J. (2006). Redacted disclosure. Journal of Accounting Research, 44, 791-814.

Wallace, R.S.O., Naser, K., \& Mora, A. (1994). The relationship between the comprehensiveness of corporate annual reports and firm characteristics in Spain. Accounting and Business Research, 25(97), 41-53.

Wallace, R.S.O., \& Naser, K. (1995). Firm specific determinants of the comprehensiveness of mandatory disclosure in the corporate annual reports of firm listed on the stock exchange of Hong Kong. Journal of Accounting and Public Policy, 14(4), 311-368.

Watson, A., Shrives, P., \& Marston, C. (2002). Voluntary disclosure of accounting ratios in the UK. British Accounting Review, 34, 289-313.

Welker, M. (1995). Disclosure policy, information asymmetry, and liquidity in equity markets. Contemporary Accounting Research, 11, Spring, 801-827.

Xie, B., Davidson, W.N., \& DaDalt, P.J. (2003). Earnings management and corporate governance: The role of the board and the audit committee. Journal of Corporate Finance, 9, 295-316.

Yu, F. (2008). Analyst coverage and earnings management. Journal of Financial Economics, 88(2), 245-271. https://doi.org/10.1016/j.jfineco.2007.05.008

Zeibote, Z., Volkova, T., \& Todorov, K. (2019). The impact of globalization on regional development and competitiveness: cases of selected regions. Insights into Regional Development, 1(1), 33-47.

Zhao, Y., \& Chen, K. (2008). Staggered boards and earnings management. The Accounting Review, 83, 1347-1381.

Zhong, K., Gribbin, D., \& Zheng, X. (2007). The effect of monitoring by outside blockholders on earnings management. Quarterly Journal of Business and Economics, 46, 37-60.

Zhou, J., \& Lobo, G.J. (2001). Disclosure quality and earnings management. Asia-Pacific Journal of Accounting and Economics, 8(1), 1-20. Retrieved from http://ssrn.com/abstract=288724

Zhou, J., \& Elder, R. (2001). Audit firm size, industry specialization and earnings management by initial public offering firms. Working Paper, State University of New York, Binghamton, U.S.

Zhu, F. (2009). Cost of capital and corporate governance: International evidence. Working Paper, University of Winconsin.

\section{Notes}

Note 1 . We acknowledge that, although efforts have been made to address the endogeneity issue, the degree of success of these efforts is uncertain. Chenhall and Moers (2007p. 219) opine that both theory and econometrics so far have been only partially successful in solving the endogeneity problem. Although a handful of studies highlight the causality issue (e.g. Beyer et al., 2010; Armstrong et al., 2010), in stark contrast Lent (2007) suggests that it is unwise to be over-concerned with a highly subjective issue like endogeneity, because the existence of endogeneity itself is uncertain and, if it does exist, there is not much that we can do to control it.

Note 2. (e.g. analyst earnings forecast and management earnings forecasts). 